\title{
Recommendations for the sale and promotion of dermocosmetic treatments at the office
}

Judith Domínguez, Emma Verástegui, Oscar Arrieta, Rubén Burgos, Carlos Campillo, Miguel Á. Celis, Manuel De la Llata, José Halabe, Sergio Islas, Luis Jasso, Alberto Lifshitz, Mucio Moreno, Ricardo Plancarte, Alejandro Reyes-Sánchez, Guillermo Ruiz-Argüelles, Antonio Soda and Julio Sotelo* Comité de Ética y Transparencia en la Relación Médico-Industria (CETREMI), Academia Nacional de Medicina de México, Mexico City, Mexico

\begin{abstract}
A novel chapter in current medical settings is the promotion and attention of esthetic aspects rather than health issues by health professionals. The human aspiration related to the search for personal beauty has generated new scenarios in medical practice. The Committee on Ethics and Transparency in the Physician-Industry Relationship (CETREMI) of the National Academy of Medicine of Mexico has analyzed this phenomenon and has issued recommendations directed both to medical professionals and to producers and potential consumers of esthetic procedures.
\end{abstract}

KEY WORDS: Dermocosmetic products. Sale at doctors' offices. Esthetics medicine.

\section{Recomendaciones para la venta y promoción en el consultorio de tratamientos dermocosméticos}

\section{Resumen}

Un capítulo novedoso es la atención y promoción por parte de médicos especialistas de aspectos relacionados con procedimientos estéticos, más que con la salud. La aspiración humana de la búsqueda de la belleza personal ha generado nuevos escenarios en la labor médica. El Comité de Ética y Transparencia en la Relación Médico Industria (CETREMI) de la Academia Nacional de México ha revisado esta circunstancia y emite recomendaciones tanto a los médicos como a los productores y potenciales consumidores de procedimientos estéticos.

PALABRAS CLAVE: Dermocosméticos. Venta en consultorios. Medicina estética.

There is growing concern in academic associations regarding the relationship between health professionals and pharmaceutical and technology industries, which directly influence on prescription through promotional activities, which in turn might induce the indication of a less effective drug or treatment, or to the detriment of patient health.

In recent years, dermatologists and plastic surgeons have been selling dermocosmetic products at their offices, and promoting different esthetic services, which is a circumstance that has generated a culture of beauty as synonymous with the aspiration to physical perfection, which can be oppressive and problematic.

Dermocosmetic products are a category of products that generate large profits; some of them have minimal or no effectiveness, and others are clearly risky.

The sale of medications/cosmetics by dermatologists and plastic surgeons is a common practice that facilitates purchasing them in an accessible place and offers products that are probably not to be found near 
the patient's place of residence. However, this type of sales also facilitates the sale of products without adequate labeling of ingredients, which hinders medical attention in case of side effects in users and obstructs accurate diagnosis.

In another scenario, pharmaceutical companies sell their products only to the doctor, in order for him/her to sell them to the patient, which means that the product does not go through a regulatory control in pharmacies.

The natural limitations in patient's medical knowledge drive him/her to seek cosmetic procedures' options at clinics, some academically recognized and others not. This lack of information results in many people buying "miracle" products at offices or esthetics clinics, or unnecessary procedures being carried out, in a search for esthetic enhancement as synonym with health. In this regard, it is important remembering that, according to the World Health Organization definition of health, personal acceptance of one's own body esthetic aspects is part of health.

For all the above reasons, the Committee for Ethics and Transparency in the Physician-Industry Relationship (CETREMI - Comité de Ética y Transparencia en la Relación Médico-Industria) issues the following recommendations:

a) For the physician who performs cosmetic procedures.

1. The procedure in question shall not be offered without the patient asking for it; if so, all adequate and detailed information about the potential risks and benefits of the cosmetic procedure being requested should be provided.

2.The physician may have dermocosmetic products for sale as long as he/she offers the patient the option of purchasing them at places authorized by regulatory agencies (clinics or pharmacies).

3.Domestically-manufactured products and without explicit details about their ingredients and formulation shall not be sold at offices or clinics.

4. We recommend physicians to refrain from participating in commercial operations.

5.Physicians who deal with dermocosmetic issues have the obligation to be certified by the council of their specialty and to show this professional information on the prescription and display it at their office or clinic.

b) For the patient.

1. The patient may or may not undergo beauty treatments, as long as he/she asks for them and has all appropriate scientific information.

2. The patient should ask for detailed information about the procedure, its benefits and possible complications.

3. The patient should verify that the doctor who will perform the procedure has a health department registration and professional license, as well as a certificate issued by the respective academic council and the necessary authorizations.

c) For the pharmaceutical industry.

1. Dermocosmetic products shall be available at established pharmacies, and should not be sold directly to doctors, in order for them not to become vendors of their products.

2.All products and technologies shall always be supported by real evidence of their benefits and risks, and have the corresponding regulatory approval.

3. The promotion of products shall always be carried out by academically qualified personnel with certified professional capacity.

\section{Funding}

This investigation did not receive any grant from agencies of the public, commercial, or non-profit sectors.

\section{Ethical disclosures}

Protection of human and animal subjects. The authors declare that no experiments were performed on humans or animals for this research.

Confidentiality of data. The authors declare that they have followed the protocols of their work center on the publication of patient data.

Right to privacy and informed consent. The authors declare that no patient data appear in this article. 